This is an electronic reprint of the original article. This reprint may differ from the original in pagination and typographic detail.

Author(s): Virtanen, Anne; Tynjälä, Päivi; Stenström, Marja-Leena

Title: $\quad$ Field-Specific Educational Practices as a Source for Students' Vocational Identity Formation

Year: $\quad 2008$

Version:

Please cite the original version:

Virtanen, A., Tynjälä, P., \& Stenström, M.-L. (2008). Field-Specific Educational Practices as a Source for Students' Vocational Identity Formation. In S. Billett, C. Harteis, \& A. Eteläpelto (Eds.), Emerging Perspectives of Workplace Learning (pp. 1934). Sense. https://doi.org/10.1163/9789087906450_003

All material supplied via JYX is protected by copyright and other intellectual property rights, and duplication or sale of all or part of any of the repository collections is not permitted, except that material may be duplicated by you for your research use or educational purposes in electronic or print form. You must obtain permission for any other use. Electronic or print copies may not be offered, whether for sale or otherwise to anyone who is not an authorised user. 


\author{
ANNE VIRTANEN, PÄIVI TYNJÄLÄ \& MARJA-LEENA \\ STENSTRÖM
}

\title{
FIELD-SPECIFIC EDUCATIONAL PRACTICES AS A SOURCE FOR STUDENTS' VOCATIONAL IDENTITY FORMATION
}

\begin{abstract}
Although work-related identity research has undergone considerable expansion in recent years, vocational identity among students remains a neglected area. However, initial vocational education plays a crucial role in the process of lifelong learning. Accordingly, this chapter discusses students' vocational identity formation during their vocational education and training. As recent findings on vocational or professional identity emphasise its context-based or sociocultural construction, we examined students' vocational identity formation in two different fields: 1) technology and transport, and 2) social services and health care. Our quantitative data indicate that while students' vocational identity formation begins during vocational education and training, there are differences between students in different fields. On the basis of our qualitative data it seems that students' vocational identity is heavily constructed in line with the education practices of their own specific fields. Thus, even during educational context has an important role in the formation of vocational identity.
\end{abstract}

\section{VOCATIONAL LEARNING AND DEVELOPMENT}

Although identity research has experienced a renaissance (Sfard \& Prusak, 2005), particularly in the area of work-related identity (see e.g. Billett, Fenwick, \& Somerville, 2006; Kirpal, 2004; Rhodes \& Scheeres, 2004), little research on vocational identity has been conducted among vocational students. However, vocational education and training (VET) can be understood as one of the first steps in the process of lifelong learning (e.g. Mitterdorff, 2006; Tennant \& Yates, 2005), and students' vocational identity formation as an initial or novice phase in their future vocational identity as employees. Recent studies have also indicated that vocational identity construction should be examined in the context where it occurs (e.g. Billett, 2006; Billett \& Somerville, 2004; Kirpal, 2004). Therefore, this chapter examines students' vocational identity formation through work-related educational practices in two vocational fields; technology and transport, and social services and health care.

The reason why we should focus on the examination of work-related educational practices, in particular, relates to our earlier findings on students' workplace learning (Tynjälä \& Virtanen, 2005; Virtanen \& Tynjälä, in press). We 
have studied students' workplace learning in different vocational fields and found surprising variety between students in different fields, particularly technology and transport on the other hand and social services and health care on the other. For example, the students in social services and health care gave higher assessments than the students in technology and transport of the knowledge and skills they acquired during their workplace learning periods (Tynjälä \& Virtanen, 2005). Differences were also found in how students experienced guidance in these two fields: the students in social services and health care reported receiving more different forms of guidance during their workplace learning periods than the students in technology and transport (Virtanen \& Tynjälä, in press). However, the social services and health care students also reported lack of guidance in their workplace learning periods more often than the technology and transport students. One explanation for these conflicting results could be that more emphasis is put on learning critical reflection in the field of social services and health care, with the result that students in this field have perhaps grown to be more critical than their counterparts in the field of technology and transport (Virtanen \& Tynjälä, in press). Thus, our earlier findings suggest that students of social services and health care have more supportive and expansive practices of learning and vocational development than students of technology and transport. In other words, different vocational fields seem to offer their students different learning environments and also different settings for their learning and vocational development. Therefore, it is important to examine more closely the educational practices and settings related to students' experiences of learning and vocational development in different fields, so as to lay bare the possible causes of the differences between them (see Rogoff, 1991).

In the present study we examined vocational development among students from two different fields with the help of the concept of vocational identity. We utilised the concept of vocational identity to determine the student's conception of her/himself as a representative of her/his own vocational field (Eteläpelto, 2007; Eteläpelto \& Vähäsantanen, 2006). The descriptions of students' vocational identity were obtained from students with questionnaire statements which reflected their identification with their own field, students' assessments of their own vocational strengths and weaknesses as well as their perceived needs for development in the future. The students' thoughts on their vocational identity formation were also collected by means of interviews concerning educational practices in the two vocational fields.

Next we describe the new work-related learning systems in Finnish VET, as it is through these systems we consider students' vocational identity formation in the two different fields. In our theoretical review we also discuss some of the constraints and challenges to the construction of vocational identity among students. Before the results section we describe the data and analytical methods used. Finally, we summarise our results and discuss how students' vocational identity is formed through the educational practices of their specific fields. 


\section{NEW WORK-RELATED LEARNING SYSTEMS IN FINNISH VET: WORKPLACE} LEARNING AND VOCATIONAL SKILLS DEMONSTRATIONS

Changes in working life and in concepts of learning and qualifications have influenced the development of formal vocational education in many countries (e.g. Streumer \& Kho, 2006). For example, Finnish VET was hugely transformed at the turn of the millennium. Due to these reforms, some parts of the curriculum are implemented in the workplace, and students' learning at work is guided by a workplace trainer. This new system is called workplace learning. In 2006, a new system, vocational skills demonstrations (VSD), was incorporated into all vocational qualifications. In this reform, students will need to demonstrate in practice how well they have achieved the objectives of their vocational studies and acquired the vocational skills required by the labour market. (Vocational education and training in Finland 2007.) Student's self-assessment is emphasised both in the assessment of workplace learning and in vocational skills demonstrations. Thus, already during their vocational education Finnish vocational students have to demonstrate their vocational skills and knowledge at work. The assessment of these attainments include students exercising the ability to autonomously assess and make visible their vocational strengths and weaknesses, in other words, show awareness of their own vocational identity and qualifications (e.g. Eteläpelto \& Vähäsantanen, 2006; see also Cohen-Scali, 2003; Côté, 1996). The Finnish National Board of Education has issued various guidelines and recommendations for organising workplace learning and vocational skills demonstrations (e.g. Vocational education and training in Finland 2007). We shall now describe workplace learning and vocational skills demonstrations as ideal cases.

Vocational qualifications take three years of full-time study, and all qualifications include at least 20 weeks of workplace learning. Usually, workplace learning is divided into two or more periods. In the early stage of studies workplace learning periods are often short, while later, when students have more skills and knowledge, workplace learning can be extended and become more specific. Students' learning at work is a component of formal vocational education and thus clearly goal-oriented: the aims for each workplace learning period are derived from the curriculum, they are written up and all the parties involved in workplace learning ( i.e. student, teacher and workplace trainer) should be aware of them. Students' learning at work is guided by teachers, and, in particularly, is assisted by workplace trainers, usually in addition to their usual duties. These trainers support the students at the workplace, give feedback and try to ensure that students' goals are reached during the workplace learning period. Students' success in workplace learning is assessed in a three-way partnership comprising student, teacher and workplace trainer.

Vocational skill demonstrations (VSD) are working situations or working processes which are designed, implemented and assessed by the education provider in cooperation with representatives of working life. Skills demonstrations run throughout the entire period of education and training. The aim is to arrange VSD in authentic working-life situations, but they may also be carried out in vocational 
schools. Before a vocational skills demonstration a student, a representative from working life and a teacher agree in a written plan what the working task(s) or the situation is in which a student has to show his/her skills and what the objects of and criteria for assessment are. This makes it clear for a student what skills and knowledge will be assessed and what criteria will be used. VSD are followed by assessment discussion in which a student, a teacher and a representative from working life take part. In particular, the teacher has to ensure that the assessment is enacted according to the assessment criteria. The assessment discussion is usually started with the student's self-assessment where the student evaluates his/her skills and knowledge against the aims and assessment criteria. The aim of the discussion is to develop students' self-assessment skills. After the students' self-assessment, a representative from working life presents his/her views of student's skills and knowledge. The teachers give their assessments last. The purpose of this procedure is to ensure that views of the representative of working life and the teacher do not direct the self-assessment of the student, nor the views of the teacher direct the views of the representative from working life. (Stenström, Laine, \& Kurvonen, 2006; Vocational education and training in Finland, 2007.)

\section{CONSTRAINTS AND CHALLENGES ON CONSTRUCTION OF VOCATIONAL IDENTITY AMONG STUDENTS}

Although vocational education has been seen to be an essential source for the development of vocational identity of students (e.g Mulder, Kahmann, Laubenbacher, \& Messmann, 2006), little research on identity has been conducted among vocational students, and it has not been possible to examine it from the same perspectives as the development of employees' vocational identity. Studies carried out among students and young people have focused more on their career identities, such as the career identity of students in the initial stage of education and their occupational commitment (see e.g. Meijers, 1998; Mitterdorff, 2006). In the present study the students are at the final stage in their vocational education, and can thus be expected to already have some degree of commitment to their own vocational field.

Identity, including professional or vocational identity, has been seen to be constructed as both social and personal, and different identity theories variously emphasise these aspects of identity (see e.g. Archer, 2000; Eteläpelto \& Vähäsantanen, 2006; Mead, 1934). Albeit recent research has showed that the construction of employees' vocational identity has become more and more individual (see e.g. Eteläpelto, 2007; Kirpal, Brown, \& Dif, 2007), we suggest that the social aspects of the formation of vocational identity are more in the forefront among students. For example, according to Harré (1983), the social construction of identity ('social identity projects'), in which the individual tries to achieve a certain bonding with the tradition, values, beliefs and practices of a community, happens before the personal construction of identity ('personal identity projects'). The individual's own unique relationship to the community and the achieved stamp in 
the community may not be shaped until after his or her adoption of the culture of the community (Harré, 1983). In this way vocational students would probably tend to identify with the staff in their workplace, with their own vocational fields etc., rather than try to create their own individual vocational identity (see Collin, Paloniemi, Virtanen, \& Eteläpelto, 2007).

Thus, the construction of personal (vocational) identity requires time and the possibility to commit to the work community. In the Finnish workplace learning system, students are members of their workplaces for just a short period, from a couple of weeks to couple of months, and after while they return to their vocational schools. They do not even aspire to be a full member of work community (see Lave \& Wenger, 1991) because their learning at work does not offer the kind of continuity which seems to promote employees' learning at work (Billett, 2004). Hence, the Finnish VET system with its school-based and work-related learning components sets up certain limits and constraints on the construction of students' vocational identity. However, students can influence their own vocational identity development. For example, asking 'stupid' questions and forming relationships with other members of workplace can foster vocational identity development (Blåka \& Filstad, 2007). Similarly, the general atmosphere and practices of the workplace, whether they are expansive or restrictive for learning (see Fuller \& Unwin, 2004), can affect the vocational identity development of students. A positive, expansive work community or learning environment supports the learning of all its members while the restrictive community limits opportunities for learning and development (Fuller \& Unwin, 2004; see also Collin, Paloniemi, Virtanen, \& Eteläpelto, 2007; Cohen-Scali, 2003; Evans, Kersch, \& Sakamoto, 2004; Tynjälä, in press).

\section{PURPOSE OF THE STUDY}

The purpose of this study is to examine students' vocational identity formation through the educational practices in two vocational fields. More specifically, we address the following research questions: 1 ) What features of students' vocational identity development can be identified during VET-related workplace learning? Are there differences between different fields of study in students' experiences of vocational identity formation? 2) What differences are there between different vocational fields in educational practices and the settings where their respective students form their vocational identity?

\section{DATA}

In this study we used data from two different research projects, one of which was gathered by questionnaires and the other by interviews. With the questionnaire data we examined the differences between the two fields of VET in certain aspects of students' perceived identity formation during their workplace learning, whereas with the interview data we probed deeper into the processes of identity formation 
in order to illuminate the differences in educational practices between the two fields. The questionnaire data were collected in Central Finland in spring 2004. The students were final-year students from six fields of VET, but for the present study we utilised data from the two biggest vocational fields, those of technology and transport, and social services and health care. These two vocational fields comprised 1125 students, of whom 661 students (59 \%) answered the Internet questionnaires. The average age of the students was 20 years, and 45 percent of them were female and 55 percent male ${ }^{1}$. The interview data were collected in spring 2005 as a part of the EU Leonardo da Vinci project in which practical skills in VET were assessed (see e.g. Stenström, Laine \& Kurvonen, 2006). For this study six interviews with Finnish students were used. The students were drawn from vocational schools piloting the new vocational skills demonstration system. All six students were also final-year students; two of them were males from the field of technology and transport, and four of them were females from the field of social services and health care.

\section{METHODS}

Students' vocational identity development was examined by a battery of questions comprising 13 statements. They sought to capture students' experiences of vocational development at the moment of answering as well as their perceived needs for development in the future. The respondents assessed every statement on a scale of 1-4 (1 = strongly disagree, 2 = disagree, 3 = agree, $4=$ strongly agree). On the basis of the results of the factor analysis four aggregate scales were formed. The content of the aggregate scales is described in the results section. The statistical significance of the differences between means in the aggregate scales were tested with t-test (independent samples t-test).

Interview data were analysed by means of content analysis. The analysis was carried out by using abductive inference (see e.g. Krippendorff, 2004) where the units of analysis were extracted from the interview data but theory was instrumental in the progress of the analysis. Expressions which described the settings of the students' vocational identity formation during vocational skills demonstrations were extracted from transcribed interviews. The expressions in question could be a clause, part of clause or a combination of several clauses (see e.g. Graneheim \& Lundman, 2004). The expressions (altogether 249) were removed from their contexts (transcribed interviews) and were each categorised by their content into one of 22 subcategories. These subcategories were then condensed into six (6) main categories. On the basis of these main categories two stories of the realisation of vocational skills demonstrations were derived. The

\footnotetext{
${ }^{1}$ In the field of technology and transport 20 percent of the respondents were women, while in social services and health care 95 percent were women.
} 
stories were then compared with each other and differences between two vocational fields were identified (Table 3$)^{2}$.

\section{RESULTS}

\section{Students' vocational identity formation in the fields of technology and transport, and social services and health care}

On the basis of the factor analysis, we formed four aggregate scales describing students' vocational identity formation during their workplace learning periods: 1) critical reflection, 2) developmental orientation, 3) strengthening of vocational identity, and 4) negative attitude towards work (Table 1). The first aggregate scale, critical reflection, focuses on changes in students' thinking during their workplace learning periods. The scale consisted of three items: "I know what my strengths and weakness are", "I realised that there are other ways to learn than those at school", and "The workplace taught me to think critically". The second aggregate scale, developmental orientation, consisted of two items: "I got ideas about how to develop my work", and "I understand that I must follow developments in my own field". The third aggregate scale, strengthening of vocational identity, consisted of two items: "During the workplace learning periods I had a feeling that I was realising my dream" and "I am beginning to feel that I am a member of my occupational group". The fourth aggregate scale consisted of three items describing negative attitude towards work: "I was not particularly interested in my work", "The workplace learning periods have made me wonder whether I am in the right field after all", and "I think that it is possible to work only for the pay". Table 1 presents the above-mentioned aggregate scales. Cronbach's alpha for every aggregate scale was at least .60 (in one case, .59) which in general is the lowest acceptable value for forming a reliable aggregate scale. Only variables that showed a correlation of at least .30 with the aggregate scale were accepted.

Table 1. Results of the factor analysis: the aggregate scales describing the students' vocational identity formation during their workplace learning periods $(n=656)$.

\begin{tabular}{llll}
\hline Aggregate scales & $\begin{array}{l}\text { Cronbach's } \\
\text { aplha }\end{array}$ & Items & $\begin{array}{l}\text { Correlation } \\
\text { of the item } \\
\text { with the } \\
\text { aggregate } \\
\text { scale }\end{array}$ \\
\hline Critical reflection & 0.66 & $\begin{array}{l}\text { I know what my strengths } \\
\text { and weakness are. }\end{array}$ & \multicolumn{1}{c}{0.49} \\
\hline
\end{tabular}

\footnotetext{
${ }^{2}$ Due to limitations of space, only the comparison between the two different fields, and not the stories themselves, is reported in this chapter.
} 


\begin{tabular}{|c|c|c|c|}
\hline & & $\begin{array}{l}\text { I realised that there are other } \\
\text { ways to learn than those at } \\
\text { school. }\end{array}$ & 0.46 \\
\hline & & $\begin{array}{l}\text { The workplace taught me to } \\
\text { think critically. }\end{array}$ & 0.45 \\
\hline \multirow[t]{2}{*}{$\begin{array}{l}\text { Developmental } \\
\text { orientation }\end{array}$} & & $\begin{array}{l}\text { I got ideas about how to } \\
\text { develop my work. }\end{array}$ & 0.42 \\
\hline & 0.59 & $\begin{array}{l}\text { I understand that I must } \\
\text { follow developments in my } \\
\text { own field. }\end{array}$ & 0.42 \\
\hline \multirow[t]{2}{*}{$\begin{array}{l}\text { Strengthening } \\
\text { vocational identity }\end{array}$} & 0.64 & $\begin{array}{l}\text { During the workplace } \\
\text { learning periods I had a } \\
\text { feeling that I was realising } \\
\text { my dream. }\end{array}$ & 0.48 \\
\hline & & $\begin{array}{l}\text { I am beginning to feel that I } \\
\text { am a member of my } \\
\text { occupational group. }\end{array}$ & 0.48 \\
\hline \multirow[t]{3}{*}{$\begin{array}{l}\text { Negative } \\
\text { towards work }\end{array}$} & & $\begin{array}{l}\text { I was not particularly } \\
\text { interested in my work. }\end{array}$ & 0.55 \\
\hline & 0.61 & $\begin{array}{l}\text { The workplace learning } \\
\text { periods have made me } \\
\text { wonder whether I am in the } \\
\text { right field after all. }\end{array}$ & 0.40 \\
\hline & & $\begin{array}{l}\text { I think that it is possible to } \\
\text { work only for the pay. }\end{array}$ & 0.32 \\
\hline
\end{tabular}

According to the results, the positive features of vocational identity (critical reflection, developmental orientation, and strengthening of vocational identity) showed moderately high values (means between 2.68-3.06, max. 4) among the students (Table 2). (A mean value over two means that most respondents agreed with the statements.) The highest mean value was for critical reflection (3.06, max. 4). Thus, the students felt that they had developed the ability to consider things more critically during their workplace learning periods. An almost equally high mean value (2.99) was for developmental orientation, which suggests that the students felt that they had a good understanding of what aspects of their knowledge and skills they would have to develop in the future. The mean value for strengthening of vocational identity was also quite high (2.68). In other words, the students reported that they had become more aware of themselves as representatives of their particular occupational group. It was rather surprising that the aggregate scale 'negative attitude towards work' also showed a high mean value (2.02). It can be explained by the fact that this battery of questions included a 
statement measuring an external motive for work ("I think that it is possible to work only for the pay”) with which the students highly agreed.

Table 2. Mean values and standard deviations of the aggregate scales describing the students' vocational identity during their workplace learning periods in two vocational fields ( $\min 1, \max 4)$

\begin{tabular}{lcccc}
\hline $\begin{array}{l}\text { Aggregate scales of } \\
\text { students' vocational } \\
\text { identity }\end{array}$ & All students & $\begin{array}{l}\text { Students of } \\
\text { technology } \\
\text { and } \\
\text { transport }\end{array}$ & $\begin{array}{l}\text { Students of } \\
\text { social } \\
\text { services and } \\
\text { health care }\end{array}$ & $\begin{array}{l}\text { Sig. } \\
\text { between } \\
\text { different } \\
\text { fields }\end{array}$ \\
& $\begin{array}{c}\mathrm{n}=656 \\
\mathrm{Mean} \text { value } \\
(\mathrm{SD})\end{array}$ & $\begin{array}{c}\mathrm{M}=428 \\
\text { Mean value } \\
(\mathrm{SD})\end{array}$ & $\begin{array}{c}\mathrm{n}=228 \\
\text { Mean value } \\
(\mathrm{SD})\end{array}$ & (t-test) \\
\hline Critical reflection & 3.06 & 2.95 & 3.26 & .000 \\
Developmental orientation & $(.53)$ & $(.51)$ & $(.51)$ & \\
& 2.99 & 2.89 & 3.18 & .000 \\
Strengthening of vocational & $(.61)$ & $(.59)$ & $(.59)$ & .000 \\
identity & 2.68 & 2.59 & 2.85 & .000 \\
Negative attitude towards & $(.71)$ & $(.69)$ & $(.72)$ & .000 \\
work & 2.02 & 2.17 & 1.74 & \\
\hline
\end{tabular}

Highly significant differences emerged between the two different vocational fields in the mean values for the aggregate scales, which described students' vocational identity (Table 2). The students from the field of social services and health care scored higher in all the factors related to positive components of vocational identity than the students from the field of technology and transport. Similarly, the students of social services and health care had a lower negative attitude towards work than the students of technology and transport.

\section{Differences in educational practices between the two vocational fields}

On the basis of the analysis of the interviews six main categories were formed describing the realisation of vocational skills demonstrations (VSD): 1) preparing for VSD, 2) conducting VSD, 3) assessment of VSD, 4) VSD as meaningful for students' learning and vocational development, 5) effects of VSD on students, and 6) needs for development of VSD. Categories 1-3 include students' descriptions of the planning and realisation of VSD, that is, they describe the chronology of the VSD and their answers from the students' perspective. The fourth category portrays the meaningfulness of VSD for the students' learning and vocational development, and the fifth category describes the effects of VSD on the motivation and emotions, such as strain or stress, of students. The sixth category refers to the students' ideas for the development of VSD. On the basis of these main categories two stories about how VSD was realised were written from the perspective of 
students in the two different fields. The comparison based on the analysis of the stories between the two different fields is summarised in Table 3. Along with the comparison it is attempted to bring into view the different structures by which education is organised in these two vocational fields as these in turn can facilitate students' learning and vocational identity formation.

Table 3. The realisation of vocational skills demonstrations (VSD), as assessed by students from two different vocational fields

\begin{tabular}{|c|c|c|}
\hline $\begin{array}{l}\text { PROCESS OF } \\
\text { VSD }\end{array}$ & $\begin{array}{l}\text { TECHNOLOGY AND } \\
\text { TRANSPORT }\end{array}$ & $\begin{array}{l}\text { SOCIAL SERVICES AND } \\
\text { HEALTH CARE }\end{array}$ \\
\hline Preparing for VSD & $\begin{array}{l}\text { - no written plan for VSD } \\
\text { - practice for VSD under the } \\
\text { vocational school teacher }\end{array}$ & $\begin{array}{l}\text { - written plan for VSD, teacher } \\
\text { and workplace trainer accept it } \\
\text { before VSD } \\
\text { - practice for VSD under } \\
\text { workplace trainer in the } \\
\text { workplace }\end{array}$ \\
\hline Conducting VSD & $\begin{array}{l}\text { - carried out mainly at the } \\
\text { vocational school } \\
\text { - more than } 10 \text { VSD during } \\
\text { education } \\
\text { - duration from a few minutes } \\
\text { to a few hours }\end{array}$ & $\begin{array}{l}\text { - carried out mainly in working } \\
\text { life at the end of workplace } \\
\text { learning periods } \\
\text { - 3-4 VSD during education } \\
\text { - duration } 2-5 \text { working days }\end{array}$ \\
\hline Assessment of VSD & $\begin{array}{l}\text { - scale of assessment 1-5 } \\
\text { - teacher accepts VSD (in } \\
\text { vocational schools and working } \\
\text { life) } \\
\text { - assessment criteria unclear to } \\
\text { students } \\
\text { - assessment discussion: teacher } \\
\text { told student how VSD went } \\
\text { - student's self-assessment: } \\
\text { sometimes, but its role not very } \\
\text { important }\end{array}$ & $\begin{array}{l}\text { - scale of assessment } 1-5 \\
\text { - workplace trainer accepts } \\
\text { VSD (in working life) } \\
\text { - assessment criteria clear to } \\
\text { students } \\
\text { - assessment discussion: } \\
\text { together with student and } \\
\text { workplace trainer (sometimes } \\
\text { teacher) } \\
\text { - student's self-assessment: } \\
\text { always, its role very important } \\
\text { (for example, assessment } \\
\text { discussion begins with } \\
\text { student's self-assessment) }\end{array}$ \\
\hline $\begin{array}{l}\text { VSD as learning } \\
\text { and vocational } \\
\text { development }\end{array}$ & $\begin{array}{l}\text { - passing VSD signals that } \\
\text { student succeeded in a small } \\
\text { component of vocational skills }\end{array}$ & $\begin{array}{l}\text { - passing VSD does not } \\
\text { guarantee that student really } \\
\text { succeeded in task/skill; rather } \\
\text { VSD is an opportunity for } \\
\text { student to get feedback about } \\
\text { her own vocational } \\
\text { development }\end{array}$ \\
\hline $\begin{array}{l}\text { Advantages and } \\
\text { disadvantages of } \\
\text { VSD }\end{array}$ & $\begin{array}{l}\text { - some students are nervous } \\
\text { about VSD } \\
\text { - students think that passing of } \\
\text { VSD has positive influence on }\end{array}$ & $\begin{array}{l}\text { - students are not nervous about } \\
\text { VSD, which is carried out in } \\
\text { familiar place (at the end of } \\
\text { workplace learning period) }\end{array}$ \\
\hline
\end{tabular}




\begin{tabular}{|c|c|c|}
\hline & employment & $\begin{array}{l}\text { - students do not think that } \\
\text { passing VSD has positive } \\
\text { influence on employment } \\
\text { (workplace learning period } \\
\text { more important) } \\
\text { - VSD slightly increases study } \\
\text { motivation of student } \\
\text { - passing VSD with good grade } \\
\text { increases self-confidence of } \\
\text { student }\end{array}$ \\
\hline $\begin{array}{l}\text { Development needs } \\
\text { of VSD }\end{array}$ & $\begin{array}{l}\text { - VSD work well in this way (at } \\
\text { school, assessed by teacher) }\end{array}$ & $\begin{array}{l}\text { - VSD work well in this way (at } \\
\text { the end of workplace learning } \\
\text { period, assessed by workplace } \\
\text { trainer) } \\
\text { - uniform duration for all VSD } \\
\text { - uniform education for all VSD } \\
\text { assessors }\end{array}$ \\
\hline
\end{tabular}

According to our interviews, the planning and realisation of VSD were very different in the two fields. The technology and transport students carried out up to 10 VSD during their education. In fact, students did not even know how many VSD they would have to carry out altogether. They practiced for VSD under the teacher at school, and it was a quite small entity and lasted from only a few minutes to a couple of hours, it was also arranged by the teacher. Students thought that the assessment was rather unexpected as the student and teacher did not discuss the VSD assessment criteria beforehand. Students did not feel that their self-assessment influenced their assessment because the teacher assessed VSD and only he/she really knew how successful it was. In contrast, the social service and health care students knew in advance when they had to carry out VSD because it was a predetermined part of certain study modules. Students had only 3-4 VSD during their education. Students planned carefully their VSD and wrote their plans up. While making this written plan students also acquainted themselves with the assessment criteria. The teacher and the workplace trainer accepted the student's plan before beginning a VSD. Vocational skills demonstrations were carried out at the end of the workplace learning period in working life so that students had the possibility to practice for them during their workplace learning. The workplace trainer who guided the student during her workplace learning also accepted the VSD. Duration of vocational skills demonstration was 2-5 working days. Assessment discussion of VSD began with the student's self-assessment. At first the students felt self-assessment to be rather challenging, but it was useful because they really had to make explicit, to express aloud what they thought their own strengthens and weaknesses were. The nature of assessment was reflective and nothing unexpected arose.

Students' attitude towards VSD as a situation for learning and vocational development was different in the two fields. The technology and transport students considered VSD as an examination or test, which went so well as than the grade showed. After passing a VSD, the students believed that they were really able to 
manage the work task or working situation in question and could move on to learning an other work task/working situation. For the social services and health care students a vocational skills demonstration was a learning situation. Even if they passed it, the students did not think it proved that they managed the task in question perfectly, but that they managed it to the level required of students. Above all, vocational skills demonstration was regarded by the students as a learning situation from which they could get feedback about their future vocational skills and knowledge for their future vocational development.

Growth of study motivation and self-confidence and also positive effect on employment were mentioned as advantages of vocational skills demonstrations. The technology and transport students thought that the VSD system was a good reform because they felt that at last someone was interested in the outcomes of work, to the extend of grading them. For these students, assessment of workplace learning was not as rigorous as the assessment of VSD. According to the students, completion of vocational skills demontration could influence their employment chances, since not all students were doing them yet (this was a piloting phase of VSD). Students thought that those who have taken their vocational education seriously before VSD were not particularly worried about it, whereas those who had neglected their vocational studies were nervous about their VSD because they had gaps in their vocational skills and knowledge. The social services and health care students reported that completion of vocational skills demonstration slightly increased their study motivation. They did not think that passing VSD would influence their employment chances very much because it was standard component of their qualification. (VSD had been piloted for longer in social services and health care than technology and transport.) Instead, passing it stimulated selfconfidence in students. The reason was that when students carried out their VSD they felt for the first time that they were "on their own", using their concrete skills and knowledge in an authentic working situation. They did not usually feel worried about them.

The social services and health care students suggested some improvements in this new system. They wished for more standardisation in how VSD were realised, including similar duration of VSD in different workplaces and equal abilities of workplace trainers to assess them. Students from both fields thought that their own field's VSD practice was workable and did not need to be redrawn.

\section{CONCLUSIONS AND DISCUSSION}

In this chapter we examined final-year students' vocational identity formation through work-related practices in two vocational fields: technology and transport, and social services and health care. According to this study, the formation of vocational identity seemed to begin among students during their vocational education and training (VET). In particular, of the components of vocational identity, critical reflection (i.e. the student's ability to assess her/his own present skills and knowledge) and developmental orientation were the strongest. However, highly significant differences between the two fields of study emerged in all the 
components of vocational identity. All the positive components of vocational identity (i.e. critical reflection, developmental orientation and strengthening of vocational identity) scored higher among the social services and health care students than technology and transport students. In contrast, the negative component of vocational identity, negative attitude towards work, was higher among the technology and transport students than social services and health care students. With the insights gained from the interviews, we suggest that different educational practices and structures of these two vocational fields create different possibilities for the formation of vocational identity among their students. The educational practices in the field of social services and health care were found to be reflective and to underline development, whereas in the field of technology and transport they were appeared to be unsystematic, fragmentary and teacher-led. On the basis of these findings, we would conclude that students' vocational identity seems to be constructed in accordance with the educational practices and structures of their particular fields.

The assessment discussion in vocational skills demonstrations (VSD) is one practice which makes visible different educational practices and settings, and which also promotes the formation of vocational identity. In social services and health care, the nature of the assessment discussion was reflective, and transparent, and it emphasised the self-assessment of students. In the assessment discussion at the end of the workplace learning period nothing of any note arose regarding students' skills and knowledge. The assessment practices emphasised students' active participation: the post-VSD assessment discussion began with the student's self-assessment, where she had to assess her own strengths and weaknesses in the VSD. In contrast, in the field of technology and transport, VSD assessment was largely teacher-led, the student's role was rather passive, and sometimes the student was surprised to find out what the teacher had noted in the assessment. Thus, assessment practice in the social services and health care field included features which are essential in the development and formation of vocational identity. For example, the identification and making visible of students' own strengths and weaknesses have been seen as essential for the individual's awareness of her or his own vocational identity (see e.g. Cohen-Scali, 2003; Côté, 1996; Eteläpelto \& Vähäsantanen, 2006). In the social services and health care, students were encouraged during the VSD process - from planning onwards - to be active, which is also a factor that strengthens vocational identity in the novice (Blåka \& Filstad, 2007).

VSD also appeared to constitute a different site of learning for the students in the two different fields. In social service and health care, VSD was above all a place of learning and vocational development. The successful completion of VSD did not mean for a student that she managed the required skills and knowledge perfectly, but that she managed them as a student. In particular, students respected the feedback from their VSD and its importance as a promoter of their own vocational development. In contrast, for the technology and transport students VSD was an achievement, passing which meant that they had successfully managed that component and could move on the next component of the qualification. For the 
students, VSD performance was simply the grade given. In sum, VSD seemed to be one unattached achievement among others for these students, whereas VSD was a learning situation that promoted and complemented the student's vocational development for the social services and health care students.

Our earlier findings suggested that the practices of the field of social service and health care also seem to foster students' workplace learning (Tynjälä \& Virtanen, 2005). In the present study, we found that the supportive and fostering features of learning emphasised in recent learning theories (see e.g. Evans, Kersch, \& Sakamoto, 2004; Fuller \& Unwin, 2004; Guile \& Griffiths, 2001; Tynjälä, in press) were present in the field of social services and health care. Because the results of students' vocational identity formation and learning at work ran parallel, we suggest that perhaps the elements which support and foster both vocational identity construction, and learning skills and knowledge are very much the same.

When the practices and structures of the field of social services and health care are considered more closely, it is apparent that the recent reforms in VET, for example, the system of vocational skills demonstrations, are being realised according to requirements set by the National Board of Education. In fact, in planning VSD - as in planning VET as a whole - the field of social services and health care seemed to be very systematic, and showed a continuous readiness further develop the education (see also Stenström, Laine, \& Kurvonen, 2006). In the field of technology and transport this was not the case. In this field, VSD seemed to be - at least in this pilot phase - a detached part of the education. Therefore, the planning of education also seemed to be rather fragmentary and organised from a short-run perspective in this particular field. The conclusion we would draw is that implementing the VSD and workplace learning systems in the field of technology and transport will need more time. Some of the practices noted in the field of social services and health care could usefully be adopted in achieving this end.

It is also important to note in this study that we examined vocational identities from the viewpoint of education rather than from the viewpoint of working life. For example, it is possible that the vocational identity of the technology and transport students appeared weaker than that of the students in social services and health care because the former identified more with working life than school. It would, therefore, be useful to find out what the possibilities and constraints on vocational identity formation are from the perspective of working life in both fields. Are these practices related to the two fields in the same way as they are from the perspective of education? It should be noted that while many recent studies on employees' workplace learning or vocational/professional identity have used data on a single employee group (the numbers have often also been rather small), the research results have been generalised across the whole research domain. Our study, reported here, indicates that there is a strong case for studying differences between employees in different fields. 


\section{ACKNOWLEDGEMENT}

The research presented in this chapter was partly supported by a grant from the Academy of Finland (Project no. 111184).

\section{REFERENCES}

Archer, M. S. (2000). Being human: The problem of agency. Cambridge: Cambridge University Press.

Billett, S. (2004). Learning through work: Workplace participatory practices In H. Rainbird, A. Fuller \& A. Munro (Eds.), Workplace learning in context (pp. 109-125). London: Routledge.

Billett, S. (2006). Work, change and workers. Dordrecht: Springer.

Billett, S., Fenwick, T., \& Somerville, M. (Eds.). (2006). Work, subjectivity and learning. Understanding learning through working life. Technical and vocational education and training series 6. Dordrecht: Springer.

Billett, B., \& Somerville, M. (2004). Transformations at work: Identity and learning. Studies in Continuing Education 26(2), 309-326.

Blåka, G., \& Filstad, C. (2007). How does a newcomer construct identity? A socio-cultural approach to workplace learning. International Journal of Lifelong Education 26(1), 59-73.

Cohen-Scali, V. (2003). The influence of family, social, and work organization in the construction of the professional identity of young adults. Journal of Career Development 29(4), 237-249.

Collin, K., Paloniemi, S., Virtanen, A., \& Eteläpelto, A. (2007, August). Constraints and challenges on learning and construction of identities at work. Paper presented the $12^{\text {th }}$ Biennial Conference of EARLI (European Association for Research on Learning and Instruction), Budapest, Hungary.

Côté, J. E. (1996). Sociocultural perspectives on identity formation: the culture-identity link and identity capital. Journal of Adolescence 19(5), 417-428.

Eteläpelto, A. (2007). Työidentiteetti ja subjektius rakenteiden ja toimijuuden ristiaallokossa. [Work identity and subjectivity in the cross-currents of structure and agency] In A. Eteläpelto, K. Collin, \& J. Saarinen (Eds.), Työ, oppiminen ja identiteetti (pp.90-142). Helsinki: WSOY.

Eteläpelto, A., \& Vähäsantanen, K. (2006). Ammatillinen identiteetti persoonallisena ja sosiaalisena konstruktiona. [Professional identity as a personal and social construction] In A. Eteläpelto \& J. Onnismaa (Eds.), Ammatillisuus ja ammatillinen kasvu (pp. 26-49). Aikuiskasvatuksen 46.vuosikirja. Kansanvalistusseura ja Aikuiskasvatuksen tutkimusseura.

Evans, K., Kersch, N., \& Sakamoto, A. (2004). Learner biographies. Exploring tacit dimensions of knowledge and skills. In H. Rainbird, A. Fuller, \& A. Munro (Eds.), Workplace learning in context (pp. 222-241). London: Routledge.

Fuller, A., \& Unwin, A. (2004). Expansive learning environments. Integrating organizational and personal development. In H. Rainbird, A. Fuller, \& A. Munro (Eds.), Workplace learning in context (pp. 126-144). London: Routledge.

Graneheim, U. H., \& Lundman, B. (2004). Qualitative content analysis in nursing research: concepts, procedures and measures to achieve trustworthiness. Nurse Education Today 24(2), 105-112.

Guile, D., \& Griffiths, T. (2001). Learning through work experience. Journal of Education and Work 14(1), 113-131.

Harré, R. (1983). Personal being. A theory for individual psychology. Oxford: Basil Blackwell.

Kirpal, S. (2004). Researching work identities on a European context. Career Development International 9(3), 199-221.

Kirpal, S., Brown, A., \& Dif, M. (2007). The individualisation of identification with work in a European perspective. In A. Brown, S. Kirpal, \& F. Rauner (Eds.), Identities at work (Technical and vocational education and training series 5, pp. 285-313). Dordrecht: Springer.

Krippendorff, K. (2004). Content analysis. An introduction to its methodology. (2 ${ }^{\text {nd }}$ ed.). Thousand Oaks: Sage Publications.

Lave, J., \& Wenger, E. (1991). Situated learning. Legimate peripherial participation. Cambridge: Cambridge University Press.

Mead, G. H. (1934). Mind, self and society. Chicago: University of Chicago Press. 


\section{AUTHOR NAMES}

Meijers, F. (1998). The development of a career identity. International Journal for the Advancement of Counselling 20, 191-207.

Mittendorff, K. (2006, May). Career development of students in prevocational and vocational education. Do students direct themselves in their career? Paper presented at the HRD Conference, Tilburg, the Netherlands.

Mulder, R., Kahmann, K., Laubenbacher, S., \& Messmann, G. (2006, October). Characteristics of learning environments in secondary vocational education and the relation with work identity. Paper presented at the EARLI SIG Professional Learning and Development Conference, Heerlen, the Netherlands.

Rhodes, C., \& Scheeres, H. (2004). Developing people in organizations: working (on) identity. Studies in Continuing Education 26(2), 175-193.

Rogoff, B. (1991). Social interaction as apprenticeship in thinking: guidance and participation in spatial planning. In L. B. Resnick, J. M. Levine \& S. D. Teasley (Eds.), Perspectives on socially shared cognition (pp. 349-364). Washington DC: American Psychological Association.

Sfard, A., \& Prusak, A. (2005). Telling identities: In search of an analytic tool for investigating learning as a culturally shaped activity. Educational Researcher 34(4), 14-22.

Stenström, M.-L., Laine, K., \& Kurvonen, L. (2006). Practice-oriented assessment - towards quality assurance through vocational skills demonstrations. In M-L. Stenström \& K. Laine (Eds.), Quality and practice in assessment. New approaches in work-related learning (pp. 89-120). University of Jyväskylä. Institute for Educational Research.

Streumer, J. N., \& Kho, M. (2006). The world of work-related learning. In J. N. Streumer (Ed.), Workrelated learning (pp. 3-49). Dortrecht: Springer.

Tennant, M., \& Yates, L. (2005). Issues of identity and knowledge in the schooling of VET: a case study of lifelong learning. International Journal of Lifelong Education 24(3), 213-225.

Tynjälä, P. (in press). Perspectives into learning at the workplace. Educational Research Review.

Tynjälä, P., \& Virtanen, A. (2005). Skill learning at work: Investigations into student experiences of onthe-job learning. Learning the Skills. Special edition of the Finnish Journal of Vocational and Professional Education, 106-116.

Virtanen, A., \& Tynjälä, P. (in press). Students' experiences of workplace learning in Finnish VET. European Journal of Vocational Training.

Vocational education and training in Finland. (2007). Retrieved October 22, 2007, from http://www.edu.fi/tonet/eng/index.html

\section{AFFILIATIONS}

\section{Anne Virtanen}

Department of Educational Sciences

University of Jyväskylä

Päivi Tynjälä

Institute for Educational Research

University of Jyväskylä

Marja-Leena Stenström

Institute for Educational Research

University of Jyväskylä 